\title{
PENGARUH KUALITAS AUDIT DAN AUDITOR SWITCHING TERHADAP MANAJEMEN LABA
}

\author{
FELITA ICASIA HADI \\ SHERLY TIFANI \\ FEB Universitas Trisakti, Jl. MH. Thamrin, Citaringgul, Kec. Babakan Madang, Bogor, Indonesia \\ sherlytf98@gmail.com, felita.icasiahadi17@gmail.com
}

\begin{abstract}
The purpose of this study is to examine the effect of audit quality and auditor switching on earnings management with fee audit as the intervening variable. Data in this study is secondary data derived from the annual report of listed companies in Indonesia Stock Exchange in 2016-2018. There are 117 sample and the method used for sampling is purposive sampling. The hypothesis ini this study was tested using multiple regression. The result of this study showed that audit quality positively influence fee audit but not significant, auditor switching negatively influence fee audit, audit quality influence earnings management with negative direction, auditor switching positively influence earnings management but not signifitcant, fee audit negatively influence earnings management but not significant, and there is no influence of variable intervening in the relationship between audit quality and auditor switching on earnings management.
\end{abstract}

Keywords: Audit quality, auditor switching, fee audit, earnings management

Abstrak: Tujuan penelitian untuk menguji apakah terdapat pengaruh dari Kualitas Audit dan Auditor Switching terhadap variabel dependen Manajemen Laba dengan Fee Audit yang diberikan sebagai variabel mediasi. Data dalam penelitian ini merupakan data sekunder dari laporan tahunan perusahaan yang terdaftar di BEl tahun 2016-2018. Sampel yang diperoleh adalah 117 dengan Purposive Sampling Method. Hipotesis yang ada dalam penelitian ini diuji menggunakan metode uji regresi berganda. Hasil yang diperoleh menunjukkan bahwa Kualitas Audit berpengaruh positif tidak signifikan terhadap Fee Audit, Auditor Switching berpengaruh negatif terhadap Fee Audit, Kualitas audit berpengaruh negatif terhadap manajemen laba, Auditor Switching berpengaruh positif tidak signifikan terhadap Manajemen Laba, Fee Audit berpengaruh negatif tidak signifikan terhadap Manajemen Laba, dan tidak terdapat pengaruh variabel mediasi fee audit dalam hubungan Kualitas Audit dan Auditor Switching terhadap Manajemen Laba.

Kata Kunci: Kualitas audit, auditor switching, fee audit, manajemen laba 


\section{PENDAHULUAN}

Laporan keuangan yang disajikan oleh perusahaan menunjukkan kinerja yang telah dicapainya pada suatu periode tertentu. Para pemakai laporan keuangan, misalnya investor dan kreditur, dalam membuat suatu keputusan seringkali mempertimbangkan prospek perusahaan, diukur berdasarkan kinerja finansial perusahaan pada satu atau lebih periode di masa lalu. Prospek yang lebih diperhatikan adalah kemampuan perusahaan memperoleh aliran kas yang berkelanjutan, sehingga aspek laba menjadi perhatian utama.

Aspek laba juga menjadi penting bagi manajer perusahaan ketika kinerjanya diukur dari kinerja perusahaan yang dikelolanya. Semakin baik kinerja perusahaan dinilai oleh pihak investor, maka semakin baik pula penilaian terhadap kinerja manajer. Sehingga seorang manajer melakukan manajemen laba agar dapat mencapai suatu tujuan tertentu, yang biasanya berupa keuntungan bagi dirinya. Manajemen laba merupakan suatu tindakan manipulasi atau merekayasa informasi dalam laporan keuangan yang dilakukan seseorang dengan sengaja demi keuntungan dirinya sendiri.

Tindakan manipulasi laporan keuangan dapat dilakukan manajer dengan memanfaatkan fleksibilitas standar akuntansi keuangan. Antara satu perusahaan dengan yang lainnya dapat menggunakan prinsip yang berbeda satu sama lain, sehingga kebenaran yang diyakini masing-masing perusahaan pun berbeda-beda (tidak ada kebenaran yang absolute, yang dapat digunakan sebagai dasar penilaian).

Para pengguna laporan keuangan sebagai pihak eksternal perlu meyakini bahwa isi laporan keuangan perusahaan bukanlah hasil manipulasi manajer yang dapat menyesatkan mereka dalam pengambilan keputusan. Untuk itu diperlukan pihak ketiga yang independen, yaitu jasa seorang akuntan publik atau auditor, demi meyakinkan para pengguna bahwa laporan keuangan perusahaan (klien) telah disajikan secara wajar sesuai PABU (Prinsip Akuntansi yang Berlaku Umum) atas segala hal yang bersifat material.

Probabilitas auditor dapat menemukan dan melaporkan segala pelanggaran pada laporan keuangan perusahaan sangat dipengaruhi kemampuan teknis dan independensi auditor. Kemampuan teknis auditor terkait pada kemampuan auditor dalam menemukan kecurangan maupun kesalahan dalam laporan keuangan dengan memenuhi standar pemeriksaan, patuh dengan SOP, dan lain sebagainya. Semakin baik kemampuan auditor, semakin tinggi kualitas audit yang diberikan.

Seorang auditor yang telah memberikan jasanya akan memperoleh imbalan atau fee audit, yang besarnya bergantung pada banyak hal, salah satunya negosiasi calon auditor dengan manajemen (sebelum dilakukan audit). Auditor yang kualitas pemeriksaannya bagus cenderung mendapatkan fee yang lebih tinggi. Namun seringkali auditor yang dibayar dengan fee tinggi menyebabkan hubungan antara auditor dengan klien menjadi bias. Tindakan ini mendorong dikesampingkannya profesionalisme, juga penurunan kualitas audit (Hartadi 2012) ketika mendeteksi manajemen laba.

Apabila seorang auditor melaksanakan penugasan audit yang terlalu lama, maka dapat terjadi penurunan independensi, sehingga berdampak pada kualitas audit yang diberikan. Auditor switching merupakan peraturan pemerintah di Indonesia untuk mencegah menurunnya independensi auditor.

Masyarakat memandang kualitas audit berdasarkan reputasi dan ukuran Kantor Akuntan Publik (KAP). Ukuran KAP yang besar dengan reputasi yang baik seperti big four dinilai dapat memberikan kualitas audit yang lebih baik dan lebih dapat diandalkan, daripada KAP non big four.

Penelitian ini mengembangkan penelitian Christiani \& Nugrahanti (2014). 
Peneliti sebelumnya memperoleh hasil bahwa kualitas audit, yang diproksikan dengan ukuran KAP (KAP big four dan KAP non big four) tidak mempengaruhi manajemen laba.

Pembeda penelitian ini dengan penelitian sebelumnya yaitu penambahan faktor auditor switching yang menjadi variabel independen. Variabel ini dipilih karena adanya artikel pendukung "Fee Audit Sebagai Pemoderasi Pengaruh Auditor Switching pada Kualitas Audit” (Putri \& Rasmini 2016).

Sample penelitian ini berupa perusahaan property, real estate, dan konstruksi yang telah listed di $\mathrm{BEI}$, periode 2016 hingga 2018, sehingga berbeda dengan penelitian sebelumnya yang menggunakan perusahaan publik yang listed di BEI periode 2016-2018. Selain itu juga ada perbedaan ukuran sampel yang diambil. Tujuan dari penelitian ini adalah untuk mengetahui ada tidaknya pengaruh kualitas audit terhadap fee audit pada perusahaan property, real estate, dan konstruksi, mengetahui ada tidaknya pengaruh auditor switching terhadap fee audit, mengetahui ada tidaknya pengaruh fee audit terhadap manajemen laba, mengetahui ada tidaknya pengaruh auditor switching terhadap manajemen laba, mengetahui ada tidaknya pengaruh kualitas audit terhadap manajemen laba.

\section{Teori keagenan}

Teori yang menjadi dasar penelitian ini adalah teori keagenan (agency theory). Teori keagenan atau teori agensi adalah teori yang menjelaskan tentang hubungan kontrak kerja antara pemilik perusahaan (sebagai principal) dan manajemen (sebagai agent). Principal adalah pihak yang mempekerjakan agent untuk mengelola perusahaannya, dengan mempercayakan pengambilan- pengambilan keputusan pengelolaan atas perusahaan pada agent tersebut.

Pada kontrak kerja ini dapat timbul konflik kepentingan (conflict of interest), dikarenakan adanya perbedaan tujuan antara manajer sebagai agent yang mengawasi kegiatan operasional perusahaan dan pemilik atau principal. Dengan mempekerjakan manajer, pemilik menginginkan adanya peningkatan shareholder value, sementara manajer menginginkan penilaian yang baik atas kinerjanya.

Manajer mengetahui lebih banyak informasi internal daripada para pemilik, sehingga manajer memiliki keharusan memberikan informasi mengenai kondisi perusahaan. Penyampaian informasi dilakukan melalui pengungkapan informasi akuntansi seperti laporan keuangan, yang kemudian menjadi pertimbangan bagi pemilik dalam membuat keputusan terkait pertumbuhan perusahaan. Ketidakseimbangan penguasaan informasi akan memicu terjadinya asimetris informasi (asymmetry information), antara manajemen (agent) dengan pemilik (principal) yang memberikan kesempatan kepada manajer untuk melakukan manajemen laba (earnings management) dengan menyesatkan pemegang saham mengenai kinerja ekonomi perusahaan (Isnanta 2008).

\section{Manajemen Laba}

Seorang manajer melakukan manajemen laba atau earnings management dengan maksud untuk kepentingan dirinya sendiri. Manajemen laba didefinisikan sebagai suatu intervensi pada laporan keuangan eksternal dengan maksud tertentu yang disengaja untuk mendapat keuntungan pribadi (Schipper dalam Pratama, Febriyanti, \& Tjiptohadi 2014). Selain itu manajemen laba juga didefinisikan sebagai tindakan dari manajer dalam penyajian laporan dengan mengubah laba periode berjalan (dengan tujuan tertentu seperti income smoothing atau tax management), tanpa mempengaruhi profitabilitas dalam jangka (Pratama et al. 2014).

Manajemen laba dapat dilakukan oleh manager dalam pelaporan keuangan, karena pembuatan laporan keuangan dapat 
menggunakan pertimbangan-pertimbangan manajer (judgment).

\section{Fee audit}

Apabila telah memberikan jasa audit, maka seorang auditor berhak menerima imbalan atau upah, berupa fee audit. Fee audit merupakan fee yang diterima oleh akuntan publik setelah memberikan jasa audit (Diandika 2017). Telah ditemukan bukti bahwa ketika auditor bernegosiasi dengan manajemen mengenai tarif fee yang harus dibayarkan pihak manajemen, maka kemungkinan besar akan mempengaruhi profesionalisme akuntan publik dan mereduksi kualitas laporan auditan (Widarti 2017).

\section{Kualitas audit}

Akuntan publik menjadi pihak eksternal yang berada di antara manajemen dan pemilik, untuk membantu memecahkan konflik perbedaan kepentingan dalam teori keagenan. Suatu audit dilakukan oleh akuntan publik untuk menilai kewajaran pada laporan keuangan suatu perusahaan (klien). Terdapat standar profesi yang harus dipenuhi seorang auditor dalam melakukan audit, dimana standar ini sekaligus menjadi indikator dalam menilai kualitas suatu audit. Standar Profesi Akuntan Publik (SPAP) yang ditetapkan oleh Ikatan Akuntan Indonesia, menjadi ukuran mutu yang wajib dipatuhi oleh akuntan publik dalam pemberian jasanya (UU No. 5 Tahun 2011).

$$
\text { Kualitas audit menunjukkan }
$$
kemampuan auditor menemukan adanya penyimpangan dalam pelaporan keuangan kliennya. Semakin banyak auditor dapat menemukan penyimpangan dalam laporan keuangan, maka kualitas audit akan dinilai semakin baik. Sehingga kualitas audit dipengaruhi oleh pengungkapan penemuanpenemuan audit (apabila didapati), yang berupa salah saji material pada pelaporan keuangan klien. Seorang auditor harus dapat mendeteksi salah saji tersebut, yang didukung bukti mengenai adanya kekeliruan ataupun kecurangan klien. Kegagalan pengungkapan salah saji material dapat memberikan dampak pada reputasi Kantor Akuntan Publik (KAP) akibat kualitas audit yang buruk.

Kualitas audit yang diberikan juga diproksikan melalui ukuran KAPnya, yang tergolong menjadi KAP Big Four dan KAP Non Big Four. KAP Big Four, yang merupakan empat kantor akuntan internasional terbesar yang dinilai memiliki keahlian dan reputasi tinggi, terdiri dari Deloitte Touche Tohmatsu, PWC (PricewaterhouseCoopers), Ernest \& Young (EY), dan KPMG. Sedangkan KAP Non Big Four merupakan akuntan di luar KAP Big Four.

\section{Auditor Switching}

Pergantian Kantor Akuntan Publik atau auditor switching dilakukan oleh perusahaan untuk mematuhi peraturan pemerintah atau dilakukan atas keinginan perusahaan itu sendiri. Auditor switching menjadi salah satu peraturan yang diwajibkan oleh pemerintah Indonesia demi mempertahankan independensi auditor. Pemerintah menetapkan peraturan bagi perusahaan untuk melakukan pergantian auditor pada 2015, yaitu PP No. 20/2015 tentang Praktik Akuntan Publik (Susanto 2018).

Auditor switching ini dilakukan untuk mempertahankan independensi auditor. Seorang Akuntan Publik dalam KAP hanya boleh melakukan audit pada satu perusahaan paling lama 3 (tiga) tahun buku berturut-turut. Apabila dari keinginan perusahaan dipengaruhi oleh faktor-faktor seperti ukuran Kantor Akuntan Publik, pertumbuhan perusahaan, financial distress, komite audit, dan lain sebagainya.

\section{Auditor Switching dan Fee Audit}

Alasan dilakukannya pergantian Kantor Akuntan Publik atas keinginan dari perusahaan itu sendiri, yaitu manajemen berusaha meningkatkan laba dengan 
mengurangi besaran fee audit yang dikeluarkan perusahaan. Karena dengan adanya auditor switching perusahaan dapat melakukan negosiasi dengan auditor yang baru sehingga memungkinkan perusahaan mengeluarkan fee audit yang lebih kecil daripada dengan auditor sebelumnya.

\section{Kualitas Audit dan Fee Audit}

Dalam bernegosiasi atas besaran fee audit yang akan dikeluarkan, perusahaan juga perlu mempertimbangkan kualitas dari audit itu sendiri. Kualitas audit yang diberikan oleh KAP Big Four dinilai lebih berkualitas daripada KAP Non Big Four. Hal inilah yang menyebabkan fee audit dari Kantor Akuntan Publik Big Four cenderung lebih tinggi.

\section{Fee Audit dan Manajemen Laba}

Sejumlah fee audit yang dibayarkan kepada auditor atas jasa audit yang diberikannya, memungkinkan terjadinya penurunan profesionalisme auditor. Penurunan profesionalisme yang terjadi akan mempengaruhi independensi auditor dalam mendeteksi manajemen laba yang dilakukan oleh manajer.

\section{Auditor Switching dan Manajemen Laba}

Keputusan perusahana untuk
meminimalkan kemungkinan terjadinya manajemen laba oleh manajer. Manajemen laba akan dapat dideteksi oleh auditor baru yang ditugaskan ketika dilakukan pergantian Kantor Akuntan Publik, yang tidak didapati oleh auditor yang bertugas sebelumnya (diakibatkan kurang kompeten atau penurunan independensi).

\section{Kualitas Audit dan Manajemen Laba}

Auditor yang dapat memberikan kualitas audit yang tinggi (dapat menemukan ketidakwajaran dalam laporan keuangan perusahaan), tentunya dapat menemukan adanya manajemen laba yang dilakukan oleh manajer. Sehingga, dengan kualitas audit yang tinggi, kemungkinan terjadinya manajemen laba perusahaan akan menurun.

Hipotesis yang diajukan sebagai berikut:

$\mathrm{H}_{1}$ : Kualitas audit berpengaruh secara positif terhadap besarnya fee audit yang diberikan.

$\mathrm{H}_{2}$ : Auditor switching berpengaruh secara negatif terhadap besarnya fee audit yang diberikan.

$\mathrm{H}_{3}$ : Kualitas audit berpengaruh secara negatif terhadap manajemen laba.

$\mathrm{H}_{4}$ : Auditor switching berpengaruh secara positif terhadap manajemen laba.

$\mathrm{H}_{5}$ : Besarnya fee audit yang diberikan berpengaruh secara positif dengan kemungkinan dilakukannya manajemen laba.

$\mathrm{H}_{6}$ : Fee audit mampu memediasi hubungan antara kualitas audit dan auditor switching terhadap manajemen laba.

\section{METODE PENELITIAN}

Objek penelitiannya adalah perusahaan property, real estate, dan konstruksi yang terdaftar di Bursa Efek Indonesia tahun 20162018. Populasi yang digunakan adalah perusahaan property, real estate, dan konstruksi yang terdaftar di Bursa Efek Indonesia (BEI). Periode penelitian yang digunakan adalah tahun 2016-2018. Dari populasi tersebut akan diambil sampel sebagai objek penelitian. Metode pengumpulan sampe yang digunakan adalah purposive sampling, dengan kriteria sebagai berikut:

1) Perusahaan property, real estate, dan konstruksi yang terdaftar di BEl yang setiap tahunnya selama periode penelitian menerbitkan laporan tahunan yaitu selama periode tahun 2016-2018.

2) Perusahaan property, real estate, dan konstruksi yang terdaftar di BEI yang menerbitkan laporan tahunan perusahaan dalam mata uang Rupiah. 
3) Perusahaan property, real estate, dan konstruksi yang terdaftar di BEI yang menerbitkan laporan tahunan auditan perusahaan dengan tanggal pelaporan 31 Desember selama periode penelitian yaitu tahun 2016-2018.

4) Mencantumkan jasa profesional dalam laporan tahunan.

5) Mencantumkan data lainnya yang dibutuhkan dari variable-variabel yang digunakan dalam penelitian ini.

Penelitian ini menggunakan jenis data sekunder yaitu laporan tahunan perusahaan yang telah diaudit periode 2016-2018 perusahaan property, real estate, dan konstruksi yang terdaftar di Bursa Efek Indonesia (BEI). Sumber datanya adalah dari situs www.idx.co.id dan website dari perusahaan yang bersangkutan.

Penelitian ini menggunakan variable dependen berupa manajemen laba, di mana pengukurannya menggunakan Discretionary Accruals dengan Modified Jones Model. Berdasarkan model tersebut, total akrual adalah gabungan dari discretionary accruals dan non-discretionary accruals (NDA). Model ini mengatakan bahwa NDA itu stabil, berdasarkan standar yang ada, tidak bergantung pada kebijakan manajemen sehingga kita hanya perlu mempertimbangkan discretionary accruals.

1. Total accurals didapat dengan rumus sebagai berikut:

$T A C t=(N / t-C F F O t)$

Dengan:

TACt $=$ Total Accruals pada periode tahun $\mathrm{t}$

$\mathrm{Nlt}=$ Net Income pada periode tahun $\mathrm{t}$

CFFOt $=$ Cash Flow from Operation pada periode tahun $\mathrm{t}$

Kemudian TAC dirumuskan sebagai berikut:

$\frac{T A C i, t}{T A i, t-1}=\beta 0 \frac{1}{T A t-1}+\beta 1 \frac{\Delta \text { Salesi,t }}{T A i, t-1}+\beta 2 \frac{\text { PPEi,t }}{T A i, t-1}+\varepsilon i \mathrm{t}$
$\mathrm{TAC}_{\mathrm{i}, \mathrm{t}}=$ total accrual perusahaan $\mathrm{i}$ pada tahun $\mathrm{t}$

$\mathrm{Ta}_{\mathrm{i}, \mathrm{t}-\mathrm{1}} \quad=$ total aset perusahaan pada tahun $\mathrm{t}-1$

$\Delta$ sales $_{i, \mathrm{t}} \quad=$ pendapatan perusahaan $\mathrm{i}$ pada tahun 1 dikurangi pendapatan i-1 $\mathrm{PPE}_{\mathrm{i}, \mathrm{t}} \quad=$ aset tetap perusahaan $\mathrm{i}$ pada tahun $\mathrm{t}$

$\mathrm{E}_{\mathrm{it}} \quad=$ error term perusahaan $\mathrm{i}$ tahun $\mathrm{t}$

2. Kemudian discretionary accrual yang kami ambila adalah dari unstandardized errornya.

Kualitas audit diproksikan dengan ukuran KAP dan diukur dengan variabel dummy. Nilai 0 untuk KAP non Big 4 dan nilai 1 untuk KAP yang berafiliasi dengan KAP Big 4. Asumsi yang digunakan adalah kalau auditor yang mengaudit berasal dari KAP big 4 memiliki kualitas audit yang lebih baik dan berkualitas dibanding dengan auditor KAP non big 4.

Auditor switching juga diukur dengan variabel dummy. Jika perusahaan yang bersangkutan mengganti auditor atau akuntan publik ataupun mengganti KAP setelah masa 3 tahun diberikan nilai 1 dan jika perusahaan tersebut tidak melakukan auditor switching diberikan nilai 0 .

Merupakan variable yang menyebabkan variable independent tidak dapat secara langsung mempengaruhi variable dependen. Variable mediasi dalam penelitian ini adalah fee audit di mana datanya diambil dari akun professional fees yang terdapat dalam laporan tahunan perusahaan property, real estate, dan konstruksi yang terdaftar di BEl.

Sebelum analisis regresi linier berganda, maka dilakukan pengujian asumsi klasik terlebih dahulu untuk menentukan variabel-variabel yang digunakan layak untuk diuji dengan regresi linier berganda. 
HASIL

Dalam penelitian ini peneliti menggunakan perusahaan property, real estate, dan konstruksi yang terdaftar di Bursa Efek Indonesia (BEI) untuk tahun 2016-2018. Dengan metode purposive sampling, diperoleh sampel sebanyak 119 data dari 39 perusahaan property, real estate, dan konstruksi untuk tiga tahun (2016-2018).

Deskripsi ini bertujuan memberikan gambaran data-data yang telah dikumpulkan dengan dinilai dari jumlah sampel, nilai maksimum, minimum, rata-rata dari setiap varibel dalam penelitian ini yaitu kualitas audit $(\mathrm{KA})$, auditor switching (AS), fee audit (FA), dan manajemen laba (DA).

\section{Tabel 1 Sampel Penelitian}

\begin{tabular}{lll}
\hline No. & Keterangan & Jumlah \\
\hline 1. & $\begin{array}{l}\text { Perusahaan property, real } \\
\text { estate, dan konstruksi yang }\end{array}$ & \\
& 84 \\
terdaftar di BEI tahun 2016- & \\
2018. & $(45)$ \\
2. & Data tidak lengkap & 39 \\
Sampel yang terkumpul & 3 \\
\hline Tahun Pengamatan & 117 \\
\hline & Jumlah sampel total selama \\
periode penelitian & & \\
\hline
\end{tabular}

Tabel 2. Deskriptif Variabel Penelitian

\begin{tabular}{lllll}
\hline Var. & Min. & Max. & Mean & Std. Dev. \\
\hline KA & 0 & 1 &, 32 &, 469 \\
AS & 0 & 1 &, 20 &, 399 \\
FA &, 00004 &, 00422 &, 0013146 &, 00105143 \\
DA &,- 16250 &, 15300 &,- 0075928 &, 06120519 \\
\hline
\end{tabular}

Tabel 3 Hasil pengujian model 1

\begin{tabular}{lllll}
\hline Indep & \multicolumn{3}{c}{ Dependen: fee audit } & Kesimpulan \\
\cline { 3 - 4 } & & & \multicolumn{3}{c}{$\begin{array}{l}\text { Sig. } \\
\text { (One- } \\
\text { tailed) }\end{array}$} \\
\hline KA &, 000 & $-1,571$ &, 0595 & $\mathrm{H}_{1}$ ditolak \\
AS &,- 001 & $-2,441$ &, 008 & $\mathrm{H}_{2}$ diterima \\
\hline
\end{tabular}

Kualitas Audit dengan proksi ukuran KAP yaitu KAP Big Four dan KAP non Big Four berpengaruh positif tapi tidak signifikan terhadap fee audit karena $p$-value dari t-statistik sebesar 0,0595>0,05 maka $\mathrm{H}_{1}$ ditolak. Auditor Switching berpengaruh negatif terhadap fee audit karena $p$-value dari t-statistik sebesar $0,008<0,05$ maka $\mathrm{H}_{2}$ diterima.

Tabel 4 Hasil pengujian model 2

\begin{tabular}{lllll}
\hline \multirow{2}{*}{$\begin{array}{l}\text { Independ } \\
\text { en }\end{array}$} & \multicolumn{2}{c}{ Dependen: manajemen laba } & Kesimpulan \\
\cline { 2 - 4 } & Koefisien $\mathrm{t}$ & $\begin{array}{l}\text { Sig. } \\
\text { (One- } \\
\text { tailed) }\end{array}$ \\
\hline KA &, 024 & 1,846 &, 034 & H3 diterima \\
AS &, 024 & 1,569 &, 060 & H4 ditolak \\
\hline
\end{tabular}

Kualitas audit berpengaruh negatif terhadap manajemen laba di mana $p$-value dari t-statistik sebesar 0,034 < 0,05 maka $\mathrm{H}_{3}$ diterima. Auditor Switching berpengaruh positif tidak signifikan terhadap manajemen laba di mana $p$-value dari t-statistik sebesar 0,060 >0,05 maka $\mathrm{H}_{4}$ ditolak.

Tabel 5 Hasil pengujian model 3

\begin{tabular}{lllll}
\hline Indep & \multicolumn{2}{l}{ Dependen: Manajemen Laba } & Kesimpula \\
\cline { 2 - 4 } enden & Koefisien $\mathrm{t}$ & $\begin{array}{l}\text { Sig. } \\
\text { (Onee- } \\
\text { tailed) }\end{array}$ & \\
\hline FA & $-4,932$ & $-1,034$ &, 1515 & H5 ditolak \\
\hline
\end{tabular}

Fee audit berpengaruh negatif tidak signifikan terhadap manajemen laba karena $p$ value dari t-statistik sebesar $0,1515>0,05$ maka $\mathrm{H}_{5}$ ditolak.

Uji sobel ini dilakukan dengan tujuan untuk menguji pengaruh mediasi fee audit terhadap pengaruh antara kualitas audit dan auditor switching terhadap manajemen laba. Dan hasil $p$-value yang diperoleh dari sobel test adalah 0,9612 artinya tidak signifikan, tidak ada pengaruh mediasi fee audit dalam hubungan Kualitas Audit dan Auditor Switching terhadap Manajemen Laba. Maka $\mathrm{H}_{6}$ ditolak. 


\section{Pengaruh Kualitas Audit dan Auditor} Switching terhadap fee audit

Dari Hipotesis 1 menyatakan bahwa kualitas audit berpengaruh secara positif terhadap fee audit, namun dari hasil statistik menunjukkan kualitas audit tidak berpengaruh signifikan terhadap fee audit. Kualitas audit yang bagus tidak menjamin fee audit lebih mahal, mungkin fee audit lebih ditentukan oleh penugasan yang diberikan serta bergantung pada keahlian yang dimiliki auditor. Hasil ini mendukung penelitian dari Rinanda dan Nurbaiti (2018). Hipotesis 2 menyatakan bahwa auditor switching berpengaruh secara negatif terhadap besarnya fee audit yang diberikan. Karena manajemen cenderung akan memilih auditor yang rendah fee nya agar bisa memperbesar laba. Selain itu juga ketika sering dilakukan auditor switching oleh perusahaan akan dipandang oleh masyarakat bahwa KAP tersebut kurang berkualitas sehingga masyarakat akan cenderung menegosiasikan fee audit yang lebih murah.

\section{Pengaruh Kualitas Audit dan Auditor Switching terhadap Manajemen Laba}

Dari Hipotesis 3 menyatakan bahwa Kualitas audit berpengaruh negatif terhadap manajemen laba dan hasil statistik juga memberikan hasil yang demikian. Artinya ketika kualitas audit suatu KAP yang baik kualitasnya maka manajer akan menghindari melakukan manajemen laba. KAP big four umumnya dikenal dengan kualitas, independensi, kemampuan dan pengalaman yang baik, dengan demikian manajer akan menghindari melakukan manajemen laba. Hasil ini mendukung penelitian dari Putu Ari Puryanti Dewi dan Ariyanto (2017). Dari Hipotesis 4 menyatakan Auditor Switching berpengaruh positif terhadap manajemen laba, namun hasil statistik menunjukkan tidak ada hubungan signifikan antara auditor switching dengan manajemen laba. Ternyata tidak terbukti bahwa ketika sering dilakukannya auditor switching bukan berarti bahwa manajer melakukannya agar bisa menurunkan biaya audit agar laba bisa meningkat.

\section{Pengaruh Fee Audit terhadap Manajemen Laba}

Hipotesis 5 menyatakan bahwa ada hubungan positif antara fee audit dengan manajemen laba. Tetapi dari hasil statistik menunjukkan tidak ada hubungan yang signifikan diantara keduanya. Hasil penelitian ini mendukung penelitian Cyntia (2014) dan Widarti (2017).

\section{Pengaruh Kualitas Audit dan Auditor Switching terhadap Manajemen Laba dengan Fee Audit sebagai variabel mediasi \\ Hipotesis 6 menyatakan bahwa fee audit} mampu memediasi hubungan antara Kualitas Audit dan Auditor Switching dengan Manajemen Laba. Namun dari hasil statistik menunjukkan tidak ada pengaruh mediasi dari fee audit dalam hubungan Kualitas Audit dan Auditor Switching terhadap Manajemen Laba. Hasil ini mendukung penelitian dari Widarti(2017).

\section{PENUTUP}

Dari hasil penelitian, pengolahan data dengan model yang digunakan adalah analisis regresi linier berganda yang telah kami lakukan, kesimpulan yang dihasilkan adalah sebagai berikut:

1. Kualitas Audit dengan proksi ukuran KAP yaitu KAP Big Four dan KAP non Big Four berpengaruh positif tapi tidak signifikan terhadap fee audit. Kualitas audit yang bagus tidak menjamin fee audit lebih mahal, mungkin fee audit lebih ditentukan oleh penugasan yang diberikan. Hasil ini mendukung penelitian dari Rinanda dan Nurbaiti(2018).

2. Auditor Switching berpengaruh negatif terhadap fee audit. Artinya ketika sering dilakukan auditor switching oleh perusahaan akan dipandang oleh 
masyarakat bahwa KAP tersebut kurang berkualitas sehingga masyarakat akan cenderung menegosiasikan fee audit yang lebih murah.

3. Kualitas audit berpengaruh negatif terhadap manajemen laba. Artinya ketika kualitas audit suatu KAP baik maka manajer akan menghindari melakukan manajemen laba. Hasil ini mendukung penelitian dari Putu Ari Puryanti Dewi dan Ariyanto (2017).

4. Auditor Switching berpengaruh positif tidak signifikan terhadap manajemen laba.

5. Fee audit berpengaruh negatif tidak signifikan terhadap manajemen laba. Hasil ini mendukung penelitian dari Widarti(2017).

6. Kemudian hasil dari sobel test untuk melihat apakah terdapat pengaruh atau tidak variabel mediasi dari fee audit antara kualitas audit dan auditor switching terhadap manajemen laba. Hasil p-value nya adalah 0,96 lebih besar dari 0,05 artinya tidak ada pengaruh variabel mediasi fee audit dalam hubungan Kualitas Audit dan Auditor Switching terhadap Manajemen Laba. Hasil ini mendukung penelitian dari Widarti(2017).

Setelah penelitian yang dilakukan telah diperoleh hasil dan juga mempertimbangkan keterbatasan-keterbatasan yang ad, diharapkan agar penelitian selanjutnya dapat memperbaiki hal-hal berikut ini:

1. Menambah tahun penelitian agar hasil yang diperoleh akan lebih akurat.

2. Memilih variabel yang lebih sesuai lagi agar hasil penelitian kita ada jurnal pendukungnya.

3. Memilih proksi kualitas audit yang lain hindari menggunakan dummy karena hasilnya cenderung tidak memuaskan. 


\section{REFERENCES:}

Widarti. 2017. Fee Audit Sebagai Mediasi Pengaruh Kualitas Audit Terhadap Manajemen Laba (Analisis Jalur). Jurnal Akuntansi, 5(1), 57. https://doi.org/10.24964/ja.v5i1.251

Christiani, I., \& Nugrahanti, Y. W. 2014. Pengaruh Kualitas Audit Terhadap Manajemen Laba. Jurnal Akuntansi Dan Keuangan, 16(1), 52-62. https://doi.org/10.9744/jak.16.1.52-62

Ciptana Putri, K., \& Rasmini, N. 2016. Fee Audit Sebagai Pemoderasi Pengaruh Auditor Switching Pada Kualitas Audit. E-Jurnal Akuntansi, 16(3), 2017- 2043.

Diandika. 2017. Financial Distress Sebagai Pemoderasi Pengaruh Fee Audit pada Auditor Switching. EJurnal Akuntansi Universitas Udayana, 18(1), 246-275.

Hartadi, B. 2012. Pengaruh Fee Audit, Rotasi Kap, Dan Reputasi Auditor Terhadap Kualitas Audit Di Bursa Efek Indonesia. EKUITAS (Jurnal Ekonomi Dan Keuangan), 16(1), 84. https://doi.org/10.24034/j25485024.y2012.v16.i1.2315

Pratama, B. A., Febriyanti, A., \& Tjiptohadi, S. 2014. Manajemen Laba : Pro- Kontra Pemaknaan Antara. Jurnal Manajemen Dan Kewirausahaan, 16(1), 55-67. https://doi.org/10.9744/jmk.16.1.55

Susanto, Yulius K. 2018. Auditor switching: management turnover, qualified opinion, audit delay, financial distress. International Journal of Business, Economics and Law, 15(5), 125-132. 